\title{
FRENCH LESSONS ON ECONOMIC GROWTH
}

\begin{abstract}
BROADSHEET entitled French Planning-Some Lessons for Britain*, written for Political and Economic Planning by M. MacLennan, seeks to indicate some of the lessons which experience of the French system of four-year plans has for Britain. Mr. MacLennan points out first that although the encouragement of growth is the primary raison d'être of planning in Britain, the contribution made by the French plans to economic growth in France has not been properly assessed in present discussions. Moreover, the system of French planning that has been taken as a model has been the particular variant operating since 1960, whereas there have been four differing plans each covering a particular phase of post-war French economic development. The concept of indicative planning appeared in a reasonably developed form only in the Third Plan (1958-61), in which, too, a first attempt was made to deal with regional development. The integration of regional planning into the national plan is carried much further in the present Fourth Plan, which attempts to formulate a growth path for the French economy, postulating both a certain rate and a certain pattern of growth. It poses difficulties similar to those which the National Economic Development Council has had to face in formulating a plan for the British economy, and in its evolution the advantages and disadvantages of French planning in circumstances similar to Britain's may be assesssed.
\end{abstract}

Planning in France, Mr. MacLennan observes, has never been the subject of ideological debate and its theoretical treatment has also been limited in scope and is a fairly recent development. He notes that while the French plans are worked out in terms of industries but implemented with the individual firm, organized labour has been excluded from the plans to a surprising extent. There is no form of incomes policy nor are the chances of receiving the co-operation of the Trade Unions in a national wages poliey regarded as high. The measures for regionalization in the Third Plan sought to reduce the economic and social costs of congestion and shortages in northern and eastern France and the under-utilization of resources in the south and west. The Fourth Plan introduces a new policy of the gradual development of infrastructure and public services in regions where agricultural, industrial and commercial expansion is spontaneous and vigorous, and in less-favoured regions, impulsive, involving bold anticipation and more aid. Adopting the policy of direct intervention, it sketches out a new regional pattorn which would create alternatives to Paris and fit in with the expansion programme of the national plan. The decentralization policy of the Third Plan had some success in limiting expansion in the Paris region, although the population of the Paris region is still growing rapidly. It is hoped that the measures

Planning. Vol. 29, No. 475 (September 9, 1963): Frenuh PlanningSame Lessons for Britain. Pp. 323-402. By Malcolm MacLennan. (London Political and Economic Planning, 1963.) 78 . outlined in the Fourth Plan may encourage among regional authorities the same change of outlook that the plans have worked among business men.

The conclusions drawn from this comparison of experience are that the French plans have operated in an economy much less open to external influence than the British economy, and the Fourth Plan is the first to direct attention to the restraints and disciplines that have dominated Britain's economic policy since the Second World War. The French system of target plans seems to have created an attitude of confidence and expansion by making economic policy a concerted affair and eliminating some of its uncertainty. To avoid the dangers in such cooperation between the State and the private sector and between industrialists themselves, adoption of similar arrangements in Britain must be combined with a soundly based policy of expansion, including probably a formal incomes poliey agreed to by the Trade Unions. The incentives used in the French planning system are geared towards remedying defects in the French economy that are not present to some extent in Britain where their effectiveness is open to question, but the integration of the regions into the national planning system is a feature that could be applied with profit in Britain.

The influence of the French plans on public expenditure is an interesting feature and the plans have provided a framework that outlines the rate of growth and distribution of public investment compatible with different overall rates of growth of output. The salient administrative features of the French planning system are likely to be necessary elements of a successful British planning system. A national plan must be based on decisions about the type of society that is desired, taken by the elected representatives of the nation, but based on a thoroughly worked-out scheme, indicating the consequences of the various options. The plan is not simply a series of measures for stimulating the growth of output, and the planning body must be sufficiently influential to make its views felt by Govern nent departments, as well as to convince business men t at they are sufficiently influential in the administration to make the plan the basis of economic policy, while sufficiently autonomous to be considered less cautiously than the work of other departments. Mr. MacLennan does not find it easy to visualize the National Economic Development Council developing along the same lines as the French system of target planning, but he regards the present Fourth Plan as providing the first working model of an indicative plan operating in an economy where price stability and balance of payments equilibrium are necessary conditions for growth. British planners, he concludes, might with profit compare the techniques used with their own, for it is this more detailed and technical interest in French planning methods which should be encouraged as the circumstances and problems of the French economy become much closer to Britain's.

\section{THE NATIONAL RESEARCH DEVELOPMENT CORPORATION}

$\mathrm{T}$ HE report and statement of accounts of the National Research Development Corporation for the year ended June 30, 1963, while published after the Trend Report, covers an earlier period and no reference is naturally made to the recommendations in that Report. The present report reaffirms the belief that with its strict control of expenditure and its small, loyal and uniquely experienced staff the Corporation has a part to play in the nation's affairs of increasing value. Of the 882 inventions communicated to the Corporation during the year, 223 were from Government Depart. ments and Research Councils, 122 from universities, 
11 each from nationalized industries and industrial research associations, and 448 from private firms and individuals in the United Kingdom. Of 146 patent rights assigned to the Corporation during the year, 101 were from Government Departments and Research Councils and 33 from universities. At the end of the year the Corporation held 366 United Kingdom patent applications and 611 granted patents, as well as 1,147 overseas patent applications and 1,232 granted patents. A further 92 United Kingdom patent applications and granted patents were held by the Corporation's subsidiary development companies as well as 631 overseas patent applica. tions and granted patents. Forty-five licence agreements were completed in the United Kingdom during the year, and altogether 523 were in force while 1,092 United Kingdom patents and patent applications are the subject of exploitation.

The Dracone project for flexible barges has been the subject of urgent scrutiny and the long-term project for fuel cells continued under direction of the subsidizing company, Energy Conversion, Ltd. Interest persisted in the antibiotic, cephalosporin $C$, but the Corporation's association with two major projects for developing scientific and commercial data processing machines, Atlas and Emidec 2400 ended as planned. The possibilities of establishing a closer relation with the Corporation was discussed with the Defence Ministries during the year with the view of ensuring that results of their research and development activitios could be made more readily available for use in civil industry where appropriate. The Joint Development Committee with the Department of Scientific and Industrial Research considered six proposals during the year, as well as five which had been submitted to that Department under a special industrial research association scherne. The Committee also discussed potential projects from a survey by the Department on instrumentation and from two other surveys sponsored by the Corporation on clinical technology, and on civil engineering/architecture/building. Proposals for assisting further advances in solid-state physics and cryogenics as well as methods for encouraging exploitation of the results of university research were considered; generally the work of this Committee seems to justify the recommendation of the Trend Committee for closer association between the Corporation and the Department of Scientific and Industrial Research.

The Corporation's 32 major revenue-earning inventions earned $£ 246,297$, of which $£ 173,000$ came from five only. At the end of the year, 33 potential development projects in various technological fields were under consideration, 16 of which were submitted by private firms. Among projects on which work was in progress or starting during the year, in addition to those already mentioned, are the aldosterone project at the Middlesex Hospital School of Medicine, an aquatic mower for clearing weeds in inland waterways, tho $A R C H$ project for electronic automatic control equipment for plant and process control, and a project for a personal guidance aid for the blind. The first prototype for the automatic analysis of milk for fat, lactose and protein content by an infra-red absorption technique is under a long-term test programme, and a reconditioned ground-nut harvester is under a further series of trials. As regards hovercraft, the main preoccupation during the year has been consideration of the need to develop in the United Kingdom and put into commercial service craft designed to meet special operational needs. Two prototype hydro-pneumatic ship fenders are undergoing trials and a study is being made of the possibilities of applying automatic techniques in medicine.

The Corporation continues to support work on the micro-organism breeding project at the Microbiological Research Establishment, Porton Down, Wilts, and a further programme of development with the oil-well drilling rig has been agreed. Work on reluctance motors is being supported to facilitate an early decision as to whether the motors have commercial applications, and a prototype of a new spectropolarimeter has been ordered. The development of a system for achieving economy in the frequency spectrum of transmitted television signals is being supported and the work on variable-speed motors is now virtually completed.

\section{THE BRITISH BROADCASTING CORPORATION}

\begin{abstract}
$\mathrm{T}$ HE debate in the House of Commons on January 14, in which the Licence and Agreement of December 19, 1963, between the Postmaster-General and the British Broadcasting Corporation was approved, was notable chiefly for the refusal of the Postmaster-General, Mr. R. Bevins, to make any increase in the present television licence fee. He admitted that this licence fee of $£ 4$ was the lowest in Europe, perhaps in the world, but claimed that now that the Corporation received almost the whole of the licence, with the increase in borrowing powers of up to $£ 20$ million for capital purposes, he thought the Corporation could meet the developing situation. He was quite unconcerned that in 1962-63 the Corporation met a deficit of $£ 2.67$ millions from reserves. Finance was in fact the main issue of the debate. At the outset the Assistant Postmaster-General, Mr. R. Mawby, admitted that while the Corporation would now receive the whole of the net licence revenue, this was still "such proportion of it as the Treasury may from time to time determine". Although, for the Opposition, Mr. A. Greenwood quoted the Government's acceptance in the White Paper of "its responsibility to see that the B.B.C. can secure sufficient income to finance adequate services", neither he nor other speakers who, like Mr. D. Gibson-Watt, thought that the right way to finance the Corporation was through the licence fee, was committed as to licence fee; however,
\end{abstract}

Mr. J. Grimond thought a $£ 6$ licenee fee would be reasonable, and was supported by Sir Robert Cary. Mr. C. Longbottom stressed the importance of guaranteed support for external services. Sir Harry Legge-Bourke was convinced that the licence fee must be a good deal higher and that more should be spent on overseas broadcasting, and apart from Mr. R. Mason no speaker other than Mr. Bevins and Mr. R. Mawby challenged the need for an early or immediate increase in the licence fee. Besides overseas broadcasting there was strong support in the debate for developments in local broadcasting, but there was little mention of educational broadcasting.

Broadcasting and education was the subject of the second lecture in the second series of B.B.C. lunch-time lectures, now published. In it Mr. J. Scupham was concerned with the ways in which broadcasting could help to fulfil educational purposes, and he began by pointing out that the B.B.C. would be starting its alternative programme B.B.C.-2 in April 1964, and by January 1966 would have gone far towards achieving national coverage. Another wave-length in tho same band had still to be allotted and a fifth and sixth wave-length could be mado available for national purposes. It was hoped soon to use the Third Programme wave-length throughout the day and that ultimately the Corporation would control a network of local stations serving every major centre of 